\title{
Frequent encounters with the seafloor increase right whales' risk of entanglement in fishing groundlines
}

\author{
Philip K. Hamilton*, Scott D. Kraus \\ Anderson Cabot Center for Ocean Life, New England Aquarium, Central Wharf, Boston, MA 02110, USA
}

\begin{abstract}
North Atlantic right whales Eubalaena glacialis utilize the entire water column and are frequently entangled in ropes from fishing gear. Data from telemetry tags have shown that right whales can swim/feed at or near the seafloor. Because those data are limited, some uncertainty remains regarding the frequency of dives to the seafloor and thus the likelihood of right whale encounters with fishing ropes there. The North Atlantic right whale photo-identification catalog was used to determine the number of sightings of right whales with seafloor sediment on their bodies and the relative frequency and geographic location of those seafloor encounters. Between 1980 and 2016, there were 2053 detections of right whales with 'mud' on their bodies, which represents $2.9 \%$ of all sightings ( $\mathrm{n}=70593)$, or $58.2 \%$ of all cataloged whales $(\mathrm{n}=730)$. Although muddy right whales were found throughout their range and in all months, $92.7 \%$ of all detections occurred in the Bay of Fundy in the summer where there was an average annual detection rate of $7.3 \%$, with a maximum of $26 \%$ of sightings in 2010. Mud was found on whales of all age classes including calves of the year, and equally among males and females. These seafloor encounters suggest that any rope resting on, or floating above, the seafloor could pose an entanglement hazard. The use of sinking groundlines likely reduces the risk of entanglements for whales swimming near the seafloor, but may not eliminate the risk for whales making contact with the sediment.
\end{abstract}

KEY WORDS: Right whale - Seafloor sediment - Mud - Bay of Fundy - Entanglement · Eubalaena glacialis

\section{INTRODUCTION}

Entanglements in fishing gear are a known source of injury and mortality to large whales in the western North Atlantic (Kraus 1990, Knowlton \& Kraus 2001, Johnson et al. 2005, 2007, Kraus et al. 2005, 2016, Glass et al. 2010, Pace et al. 2014). In particular, entanglement in fishing gear has been identified as one of the major threats to the survival of North Atlantic right whales (hereafter referred to as right whales) by the US National Marine Fisheries Service (NMFS 2005). There were an estimated 458 animals in this population in 2015 (Pace et al. 2017) and an estimated 5.6 right whales died or were seriously

*Corresponding author: phamiltn@neaq.org injured each year from 2010-2014, 4.6 of those from entanglements (Hayes et al. 2017). Further, an assessment of entanglements documented through 2016 showed $84.7 \%$ of the cataloged right whales had scars from encounters with fishing gear (Knowlton et al. 2018). Fishing rope strength has been increasing, contributing to an increase in the severity (Knowlton et al. 2016) and lethality (van der Hoop et al. 2013, Robbins et al. 2015) of these entanglements. Entanglement mortalities increased from $21 \%$ of all documented mortalities from $1970-2002$ to $51 \%$ from 2003-2018 (Sharp et al. 2019). For those whales that survive the initial entanglement but have gear attached, the drag from that gear can negatively

() The authors 2019. Open Access under Creative Commons by Attribution Licence. Use, distribution and reproduction are unrestricted. Authors and original publication must be credited. 
impact their energy budget (van der Hoop et al. 2016) and can cause pain and suffering (Moore \& van der Hoop 2012). Recovered fishing gear from whales that have been disentangled (or from carcasses) includes a variety of both US and Canadian fixed gear, primarily from pot or trap fisheries and gillnets (Johnson et al. 2005).

Three types of fixed fishing gear may create a risk of near seafloor entanglements for right whales: groundfish gillnets, bottom-set long lines, and pot/ trap gear. Groundfish gillnets are set in a variety of configurations and sizes, but generally have floats at the top and weights at the bottom that stretch the net from 2-10 m vertically, are anchored at both ends, and set on the seafloor. Gillnets are set in 'strings' of $100 \mathrm{~m}$ nets tied end to end, sometimes reaching combined lengths of $2000 \mathrm{~m}$. Groundfish longlines are ropes to which shorter lines with baited hooks are attached at regular intervals. Longlines are anchored at both ends, generally lie on or near the seafloor, and can stretch several miles. Finally, there are a variety of pot fisheries directed at invertebrates (lobster, crab, whelk, shrimp), hagfish, and in some areas, pelagic fish. Once again, there is large variation in pot fishery configurations, but as these fisheries move into deeper water, multiple pots or traps get strung together, with each trap connected to the next one by a 'groundline'. Groundlines traditionally were made with floating rope to avoid chafing with rocks on the seafloor, but starting in April 2008, NMFS required all pot fishermen in the Northeast USA seaward of an exemption line in Maine to use sinking groundlines (NMFS 2007). Canada has no such regulations on groundlines. Floating groundlines have an arc height of 1-5 $\mathrm{m}$ above the seafloor depending on the currents and how closely spaced the traps in the trawl are set (McKiernan et al. 2002, Brillant \& Trippel 2010). Brillant \& Trippel (2010) showed average arc heights of 1-2 $\mathrm{m}$ for groundlines between Canadian lobster traps in the Bay of Fundy and suggested that these ropes present a low risk to right whales because they are less than the $3 \mathrm{~m}$ diameter of a right whale's body.

Fishermen have suggested that right whales may not overlap with their gear or dive to the seafloor in some areas, and therefore the use of floating groundlines in those areas may be safe (Johnson et al. 2007). Detailed research on right whale diving behavior using telemetry tags revealed that this species can dive to depths of at least $174 \mathrm{~m}$ and feeds at whatever depths high concentrations of copepods occur (Baumgartner \& Mate 2003, Baumgartner et al. 2017). These concentrations primarily occur near the sur- face, just above the bottom mixed layer (approximately 50-75 $\mathrm{m}$ above the seafloor), or as close as $5 \mathrm{~m}$ off the seafloor. Baumgartner et al. (2017) found nearly one-quarter of the 55 whales tagged dove to the seafloor and they did so in all but one habitat. Most, but not all, of those whales appeared to be feeding near the seafloor. Even in Cape Cod Bay, where right whales often feed at the surface (Mayo \& Marx 1990), they occasionally feed near the seafloor (Baumgartner et al. 2017). Both Mate et al. (1997) and Baumgartner \& Mate (2003) observed right whales making non-feeding, ' $\mathrm{v}$ ' shaped, exploratory dives to the seafloor throughout their feeding range.

Given that some US fishermen question the need for sinking groundlines in US waters, and a debate remains whether they should be adopted in Canadian waters, additional data on right whale dive behavior is needed. Here, we used the North Atlantic Right Whale Catalog, which is the repository for all photographed right whale sightings in the North Atlantic, to evaluate right whale encounters with seafloor sediments as indicated by photographs of mud on their bodies. The Catalog data provide a much larger sample size than the dozens of tagged whales whose dive depths have been previously recorded. We examined the frequency, distribution, and characteristics of such seafloor encounters in order to evaluate the risks of entanglement in fishing gear placed near the ocean floor.

\section{MATERIALS AND METHODS}

Right whales are individually identifiable by a combination of the callosity pattern on their heads (Payne et al. 1983, Kraus et al. 1986) and scars (Kraus 1990). The North Atlantic Right Whale Catalog contains all known photographed sightings of right whales from 1935 to the present (Hamilton et al. 2007). Most right whale photographs were collected by dedicated survey teams studying right whales along the eastern seaboard of North America, but the Catalog also includes opportunistic sightings from teams focused on other species, government agencies, and the public. The Catalog contains sightings of whales that have been matched to known individuals, as well as sightings that have either not been matched yet, or whose image quality is too poor to ever match. Each sighting record in the Catalog includes the time, location, and additional information about behavior or other distinctive features of the sighting. If the same whale was photographed several times with more than $1 \mathrm{~h}$ between sightings or 
changed its behavior, then the latter sighting is included as a separate sighting. One of the features routinely noted in the database is the presence of 'mud' on the whale's head or body-an indication that the whale had come in contact with the seafloor in the recent past. The term 'mud' as used here likely includes a variety of soft seafloor sediments (clay, silt, or mud), with the common characteristic being adherence to the whale so that it is easily observed in the field and in photographs of each sighting (Fig. 1). Mud is mostly found on the head (the dorsal rostrum, lower jaw, or chin), but it can also be seen on the flank or flukes, although such observations are rare. All records in the Catalog from 1980-2016 were queried for the notation of mud.

All sightings with mud were then used to determine the frequency of their occurrence according to sex and age class. For those sightings matched to the Catalog, the age class and sex of the whale were determined from each whale's full sighting history.
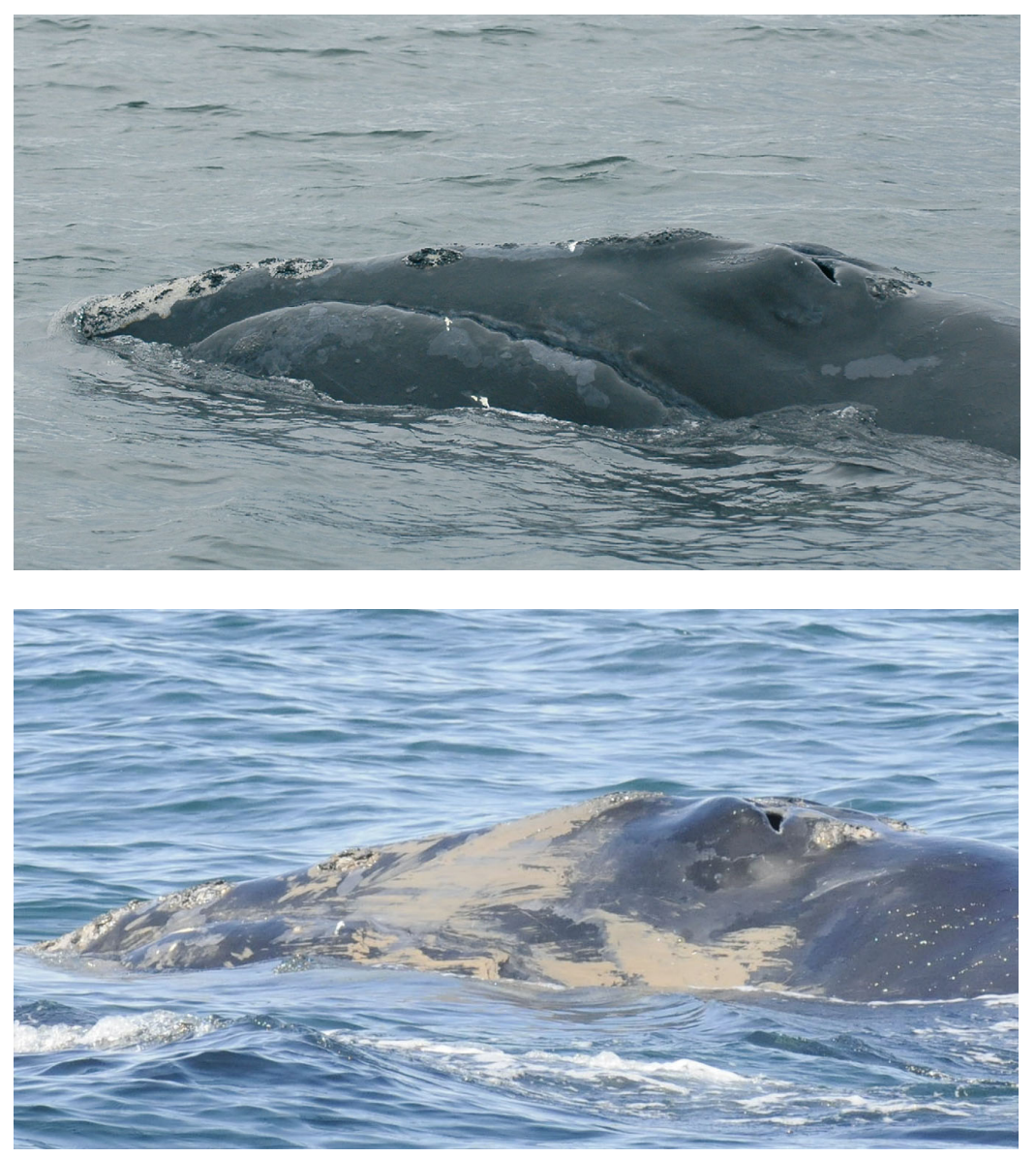

Fig. 1. North Atlantic right whale No. 2710 (top) without and (bottom) with mud on the left side of its rostrum and lower jaw. Photo credits: Top: Amy Knowlton/Anderson Cabot Center at the New England Aquarium; Bottom: Jessica Taylor/Anderson Cabot Center at the New England Aquarium
Sex was determined genetically (Brown et al. 1994), by photographs of the genitals (Payne et al. 1983), or by repeated association with a calf (Knowlton et al. 1994). To determine if one sex was more likely to be observed with mud, the known sex of the muddy whales was compared to the known sex in the overall population using a Pearson chi-squared test in SPSS v.24 (IBM). Age class was defined as (1) adultknown age of $9 \mathrm{yr}$ or older, or the year before a first calving, or unknown age and a sighting history of $8 \mathrm{yr}$ or more in that year; (2) juvenile-nulliparous, known-age 1 to 8 ; or (3) calf - the first year of life (Hamilton et al. 1998). All nulliparous whales of unknown age with sighting histories of less than $8 \mathrm{yr}$ were categorized as of unknown age class.

Since almost all sightings in the Catalog include photographs of the head, sightings with mud on the head were compared to all sightings to determine if there was variation in seafloor encounters by region. The number of whales showing mud was calculated as a percentage of the total number of sightings by study area. To explore annual variations in mud occurrence, data from the Bay of Fundy (where more than $90 \%$ of the mud sightings occurred; Fig. 2) were used to show annual percentages. The Bay of Fundy data are the most comparable from year to year as that habitat has been surveyed annually utilizing the same survey platform and protocols since 1980 (Brown et al. 2007, Davies et al. 2019).

To determine whether whales were diving to the seafloor in the same habitat where the mud was detected, or getting muddy elsewhere and immigrating into the area, a subset of whales that were seen multiple times in a day were analyzed to assess mud acquisition and persistence. To facilitate the review of images for this analysis, only sightings with digital images were used which limited the data to the years 2003-2016. Any whale during this time period that was seen multiple times in a day and had mud on its body during at least one of those sightings was included. Cases of possible mud acquisition (records noted without mud and then with mud), loss (with mud and later without), and retention (with mud in 2 or more records on that day) were tal- 


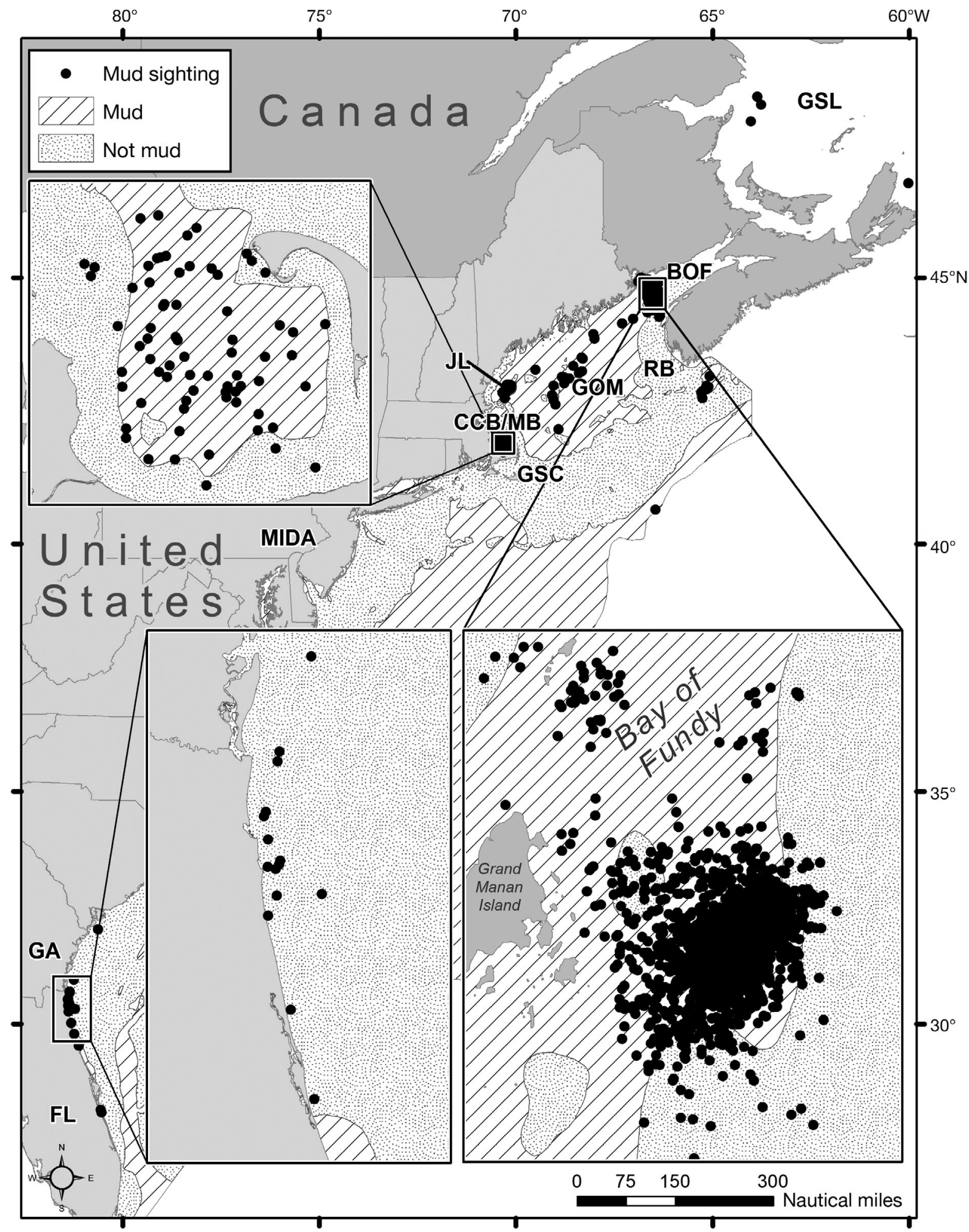

Fig. 2. Sightings of right whales with mud on their bodies along the eastern seaboard of North America overlaid on seafloor sediment type, 1980-2016. See Table 1 for list of acronyms; GA: Georgia; FL: Florida. Hatching: areas of seafloor that are comprised of mud or clay substrate. There were no mud detections in the areas on the chart that are hidden by the inset maps. Sediment data from USGS (2005) can be found at https://woodshole.er.usgs.gov/openfile/of2005-1001/data/ 
lied. Because photo quality can impact the ability to detect mud, and because mud can occur on just one side of the whale and both sides of the whale are not photographed at every sighting, each case of apparent acquisition or retention had to be inspected before the mud or lack of mud status could be confirmed. The goal was to determine whether mud was acquired in that habitat and how long it could persist. All cases of potential acquisition were reviewed, and those records for which mud was seen in 2 different sightings more than $1 \mathrm{~h}$ apart were reviewed for retention. If the placement and pattern of mud were the same, then it was counted as a mud retention and the time between those sightings calculated. To determine whether mud could persist into the next day, images of all whales seen with mud on 2 consecutive days were reviewed. Finally, some records of potential mud loss were spot checked to confirm mud could be lost in the same day.

To determine the spatial extent of right whale encounters with the seafloor and their relation to seafloor sediment type, ArcMap v.10.6.1 (ESRI) was used to plot all mud data along the east coast of North America in relation to sediment type. Seafloor sediment determinations were based upon US Geological Survey maps (USGS 2005).

\section{RESULTS}

\subsection{Occurrence of mud}

A total of 2053 sightings of right whales with mud between 1980 and 2016 were confirmed, $92.69 \%$ of which were in the Bay of Fundy (Table 1). Sightings with mud occurred in all months (Fig. 3; May has 1 sighting). The sightings include 2008 sightings that were matched to the Catalog (Table 2). Those records represented 425 different individuals seen with mud on $1731 \mathrm{~d}$ (i.e. only 1 sighting $\mathrm{d}^{-1}$ whale $^{-1}$ ), with some individuals observed with mud on as many as $26 \mathrm{~d}$ over the years. These 425 individuals represent $58.2 \%$ of all the cataloged whales seen during the study period $(\mathrm{n}=730)$. All age classes were seen with mud, including 140 cases of mud on calves of the year (Table 2). The proportion of males to females was not significantly different than that found in the entire catalog $\left(\chi^{2}=0.288, p=\right.$
Table 1. Sightings of right whales with mud on their bodies by study area. BOF: Bay of Fundy; JL: Jeffreys Ledge (east of New Hampshire); GSL: Gulf of St. Lawrence; GOM: Gulf of Maine; CCB/MB: Cape Cod Bay/Massachusetts Bay; RB: Roseway Basin (south of Nova Scotia); SEUS: Southeastern USA (coastal waters of Georgia and eastern Florida); MIDA: Mid Atlantic (south of Cape Cod to the Georgia/South Carolina border); GSC: Great South Channel

\begin{tabular}{|lcccc|}
\hline Area & $\begin{array}{c}\text { No. of } \\
\text { sightings } \\
\text { with mud }\end{array}$ & $\begin{array}{c}\text { Percent } \\
\text { of all mud } \\
\text { sightings }\end{array}$ & $\begin{array}{c}\text { Total } \\
\text { no. of } \\
\text { sightings }\end{array}$ & $\begin{array}{c}\text { Minimum sea- } \\
\text { floor encounter } \\
\text { rate (\%) }\end{array}$ \\
\hline BOF & 1903 & 92.69 & 25973 & 7.33 \\
JL & 20 & 0.97 & 1120 & 1.79 \\
GSL & 6 & 0.29 & 491 & 1.22 \\
GOM & 23 & 1.12 & 2339 & 0.98 \\
CCB/MB & 72 & 3.51 & 14971 & 0.48 \\
RB & 12 & 0.59 & 2778 & 0.43 \\
SEUS & 15 & 0.73 & 15173 & 0.10 \\
MIDA & 1 & 0.05 & 1197 & 0.08 \\
GSC & 1 & 0.05 & 6551 & 0.02 \\
Total & 2053 & & 70593 & \\
\hline
\end{tabular}

0.592). In some cases, mud was visible on one side of the head and not the other, suggesting that some animals are swimming on their sides when they encounter the seafloor.

\subsection{Distribution and locations of seafloor encounters}

Right whales were seen with mud in most of the study areas (Table 1, Fig. 2). With all years combined, the highest percentage of sightings with mud was in

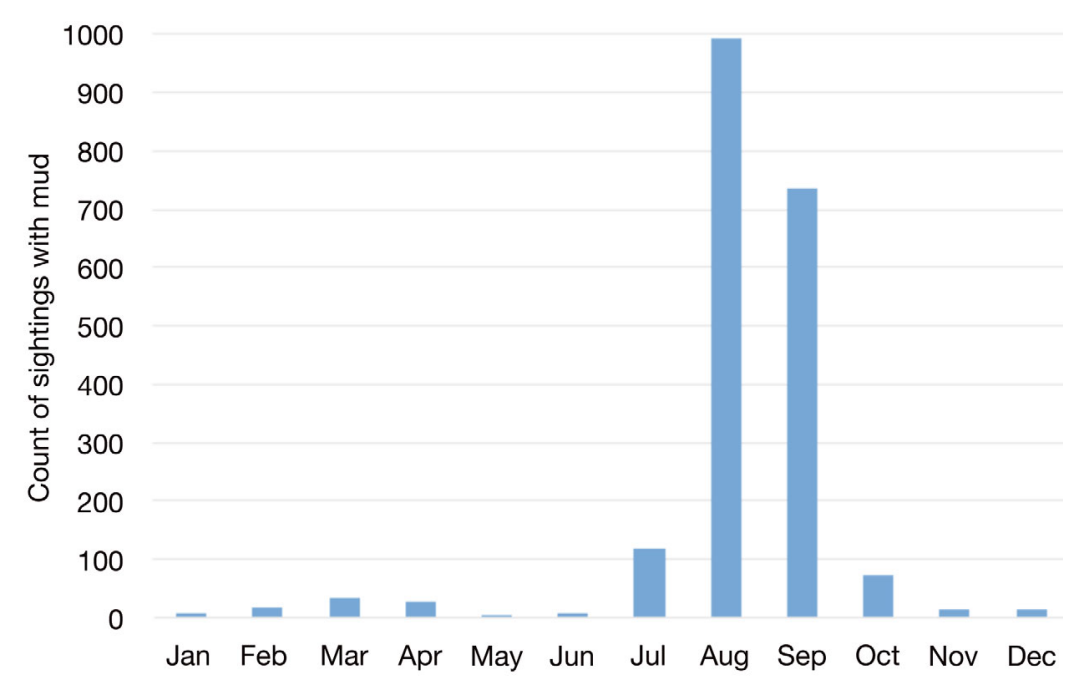

Fig. 3. Number of mud detections on right whales by month 
Table 2. Age and sex of the 2008 identified right whales seen with mud on their bodies from all areas: 1980-2016

\begin{tabular}{|lcc|}
\hline Age, sex & Count & Percent of total \\
\hline Age class & & \\
Adult & 1022 & 51.0 \\
Juvenile & 704 & 35.1 \\
Calf & 140 & 7.0 \\
Unknown & 142 & 7.1 \\
Sex & & \\
Female & 944 & 47.0 \\
Male & 1050 & 52.3 \\
Unknown & 14 & 0.7 \\
\hline
\end{tabular}

the Bay of Fundy (7.33\%), followed by Jeffreys Ledge (NH), Gulf of St. Lawrence, and Gulf of Maine habitats at $1.79,1.22$, and $0.98 \%$ respectively. Two of the remaining 3 northern (feeding) habitats had mud rates of 0.43 and $0.48 \%$. The Great South Channel had a near absence of mud with only 1 out of 6551 sightings, even though portions of the area have mud in the seafloor. One out of 1197 sightings in the midAtlantic (south of Cape Cod, MA, to the Georgia/South Carolina border) had mud, although that region had less mud sediment than other areas in the analysis (Fig. 2). In the coastal waters of the southeastern USA, the primary winter calving ground for right whales, the percentage of sightings with mud was low $(0.10 \%)$ (Table 1$)$. Because this is the only habitat in which right whales are not believed to feed, images from the 15 sightings of whales with mud in the region were inspected to confirm the presence of mud. Whales were seen to acquire mud within minutes (i.e. dive without mud and surface minutes later with mud) and also lose mud within minutes to $1 \mathrm{~h}$, indicating that they are hitting the seafloor there.

\subsection{Annual variation}

As more than $92 \%$ of mud sightings occurred in the Bay of Fundy (Table 1), data from that habitat were used to explore annual variation in occurrence of mud on whales. Between 1980 and 2016, right whales were observed 1903 times in the Bay of Fundy with mud on their heads or bodies. Annual variation was large (Fig. 4), ranging from about $1 \%$ of all sightings in 1980 to $26 \%$ in 2010 (mean \pm SD: $8.1 \pm 0.056 \%$ ).

\subsection{Timing of mud: acquisition and persistence}

From 2003-2016, there were 790 sightings of 167 different right whales seen on 318 different days where that whale was seen multiple times in a day and had mud on its body during at least one of those sightings. These 790 sightings resulted in the possible detection of whales gaining mud ( $\mathrm{n}=104)$, losing mud $(\mathrm{n}=143)$, and retaining the mud $(\mathrm{n}=118)$. Of the 104 cases of potential acquisition, only 38 could be

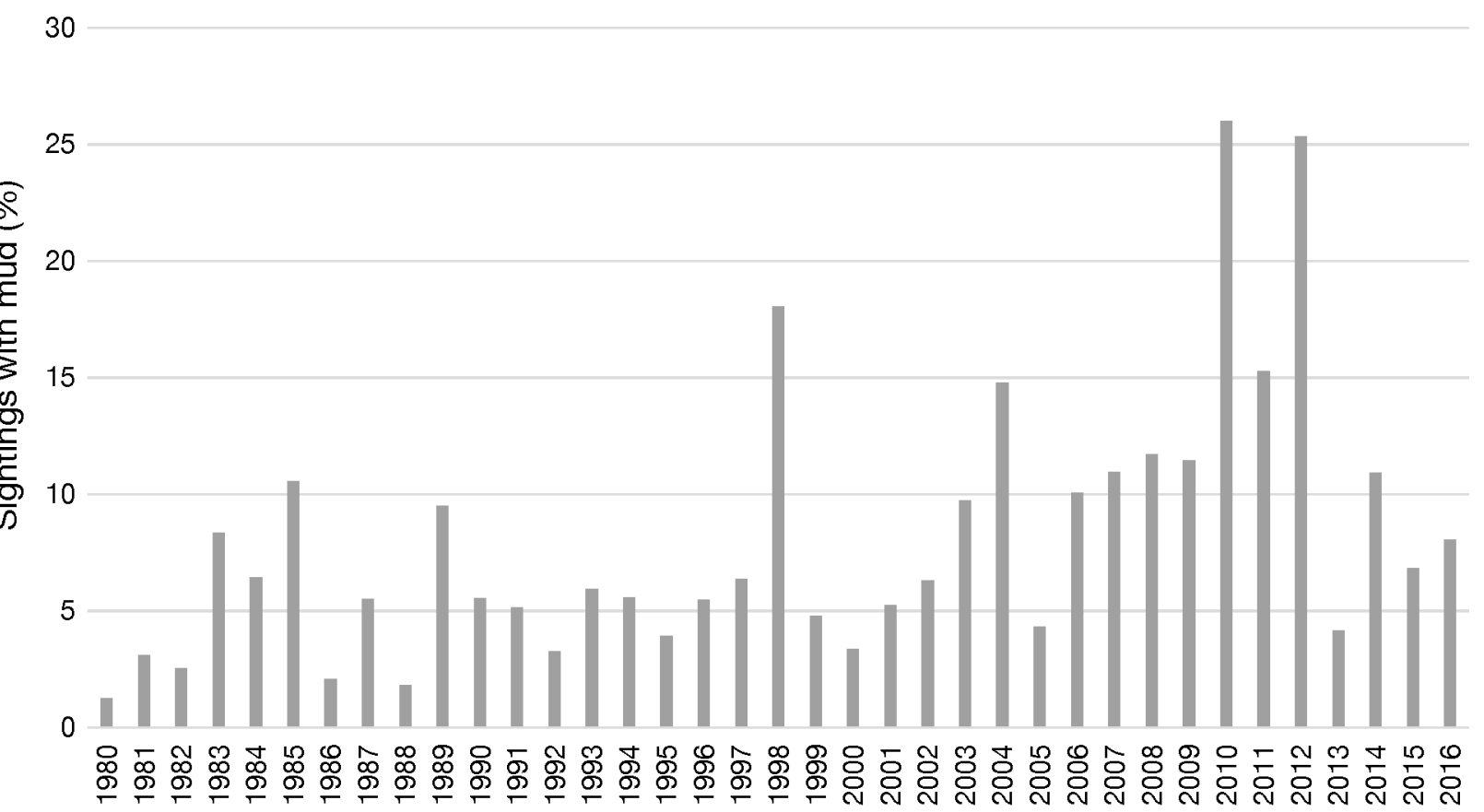

Fig. 4. Annual percentage of sightings of right whales in the Bay of Fundy with mud on their bodies 
confirmed as newly acquired mud. Of those 38, 19 $(50 \%)$ were on whales that were seen in a surface active group (SAG) during that sighting, or in the sighting immediately preceding that sighting (meaning it could have become muddy during the SAG, but after the researchers departed); 11 were on mothers with calves or on the calves $(28.9 \%)$, and $8(21.1 \%)$ were on individuals where no behavior was recorded. There were 118 potential detections of mud retention, 68 of which were sightings that were $1 \mathrm{~h}$ or more apart. In 8 of the 68 , it could not be confirmed whether the mud came from one or more seafloor encounters because the same muddy body part was not photographed at the later sighting. The remaining 60 cases were all confirmed as mud persisting across sightings; i.e. the location and pattern of the mud from the earlier sighting matched that from the later sighting(s). The mean persistence time was $2.25 \mathrm{~h}$ with a maximum of $5.5 \mathrm{~h}(\mathrm{SD} \pm \mathrm{SE}: 75.1 \pm$ $9.7 \mathrm{~min})$. These data represent minimum persistence times since mud was already on the head for an undetermined period of time at the first sighting and likely persisted for some time after the later sighting. All but 3 of the 60 cases of persistence within $1 \mathrm{~d}$ were from the Bay of Fundy; the other 3 included 1 off the coast of Florida and 2 in Cape Cod Bay, MA. To spot check the occurrence of potential mud loss, 44 of the 143 cases were reviewed. One-third of those were confirmed as mud loss within the day (16 confirmed loss, 7 not lost, 21 could not be determined).

To assess whether mud could persist for more than $1 \mathrm{~d}, 35$ whales that were seen with mud on 2 consecutive days were analyzed. In 2 cases, the mud pattern clearly persisted for $1 \mathrm{~d}$, and in a third case, it may have persisted for $2 \mathrm{~d}$. Most of the 35 cases showed clear evidence of a second (at a minimum) encounter with the seafloor. In some cases, some of the earlier mud may have remained, but clearly new mud had been acquired. Interestingly, many of those resulted in mud on the same specific location on the head, suggesting that whales were either purposefully making seafloor contact with that part of their head, or they have a specific feeding style that results in that part of their head hitting the seafloor.

\section{DISCUSSION}

The data presented here support the findings by Baumgartner et al. (2017) that right whales dive to the seafloor in most study areas. In that study, the authors found that 15 of the 55 tagged whales dove to within 0 to $10 \mathrm{~m}$ of the seafloor and they did so in 5 out of the 6 study sites. The data presented here increase that sample size to 2053 encounters involving at least 425 individuals, or $58.2 \%$ of cataloged whales, that made contact with the seafloor (Table 1 , Fig. 3). These data also provide information not available in the Baumgartner et al. (2017) study. This includes demographic data showing that males and females are equally likely to swim to the seafloor, and that calves are also interacting with the seafloor and thus are at risk there. These encounters occur in all months and include areas where feeding is not believed to occur. Finally, these data prove that whales are making physical contact with the seafloor, something that the tagging studies could not determine.

\subsection{Annual mud variation in the Bay of Fundy}

Another unique aspect of the data presented here is the time-series they provide for the Bay of Fundy (Fig. 4). The inter-annual variability in the Bay of Fundy data demonstrates that tagging data from just 1 or 2 yr may not capture the whole picture of right whale diving behavior in the area. It is interesting to note that 3 of the 4 highest years for mud detection in the Bay occurred during an ocean-wide distribution shift in right whale occurrence. Starting in 2010, right whale numbers in 3 of their 4 feeding habitats began to decrease, and that pattern has persisted to the present (Pace et al. 2017, Hayes et al. 2018). The years 2010-2012 marked some of the highest incidence of mud in the Bay. Although only speculative, it is possible that right whales shifted where, how, and upon what they fed during that transition time.

\subsection{Why right whales make contact with the seafloor}

The data suggest that right whales go to the seafloor for multiple reasons. Some of the encounters likely involve feeding. Goodyear (1996) described right whales spending significant amounts of time near the seafloor in the Bay of Fundy. Baumgartner et al. (2017) described typical ' $U$ ' shaped feeding dives to dense plankton aggregations near the seafloor in Jeffreys Ledge and the Great South Channel. Other researchers have reported comparable high-density plankton patches near the seafloor, where diapausing and vertically migrating Calanus finmarchicus are known to occur (Visser \& Jónasdóttir 1999). Right whales may accidentally hit the seafloor while feeding on these dense Calanus patches. 
Although not yet documented, it is possible that right whales may occasionally feed on invertebrates in the seabed. Bowhead and gray whales have been documented with mud streaming out of their mouths and occasionally on their rostrum indicating feeding on organisms in the sediment (Wursig et al. 1989, Moore et al. 2003, Clarke et al. 2016). There are anecdotal reports of sediment coming out of the mouths of right whales (P. Hamilton unpubl. data), but interestingly none are in the Bay of Fundy where mud on the head predominates. One record is from off the coast of Florida and the rest are in Cape Cod Bay, MA. In 1989, to explore the hypothesis of seafloor feeding, a remotely operated vehicle (ROV; MiniRover 3000) equipped with high-resolution cameras was lowered to the seafloor 11 times in the Bay of Fundy in areas where right whales had been seen with mud. Although bottom marks and grooves from right whales were documented, bottom grabs yielded no benthic amphipods or other potential prey ( $\mathrm{S}$. Kraus unpubl. data). Still, this hypothesis could be explored further, perhaps by investigating the fecal contents of whales in the Bay of Fundy.

Other encounters are likely not related to feeding. Right whales interact with the seafloor on the calving ground off the southeastern USA where they are not believed to feed (Lockyer 1984). Further, the fact that $50 \%$ of the mud acquisition detections occurred dur- ing, or around the same time as, SAGs suggests that at least some seafloor encounters may not be related to foraging. SAGs are often hectic interactions involving anywhere from 2 to over 40 whales socializing, touching, and mating (Kraus \& Hatch 2001, Parks et al. 2007). Besides encounters during SAGs and directed feeding bouts, there may be additional explanations for right whale encounters with the seafloor. One hypothesis is that right whales may be scratching themselves on the ocean floor, possibly to remove cyamids or loose skin. A recent study on bowhead whales showed that species rubs on the rocky seafloor to help exfoliate (Fortune et al. 2017). It is unclear if a mud seafloor could serve the same function for right whales. A cursory examination of the skin of whales with mud showed a range of skin conditions with both sloughing skin and healthy, black skin observed, but this hypothesis cannot be ruled out.

\subsection{Risk of seafloor encounters}

Regardless of the reason for the mud acquisition, seafloor-diving behavior increases the risk for right whales to become entangled in lines near the ocean floor, and it is clear that both sexes and all age classes are at risk. When a right whale is feeding, both the upper rostrum and the lower jaw are potential 'hooks'

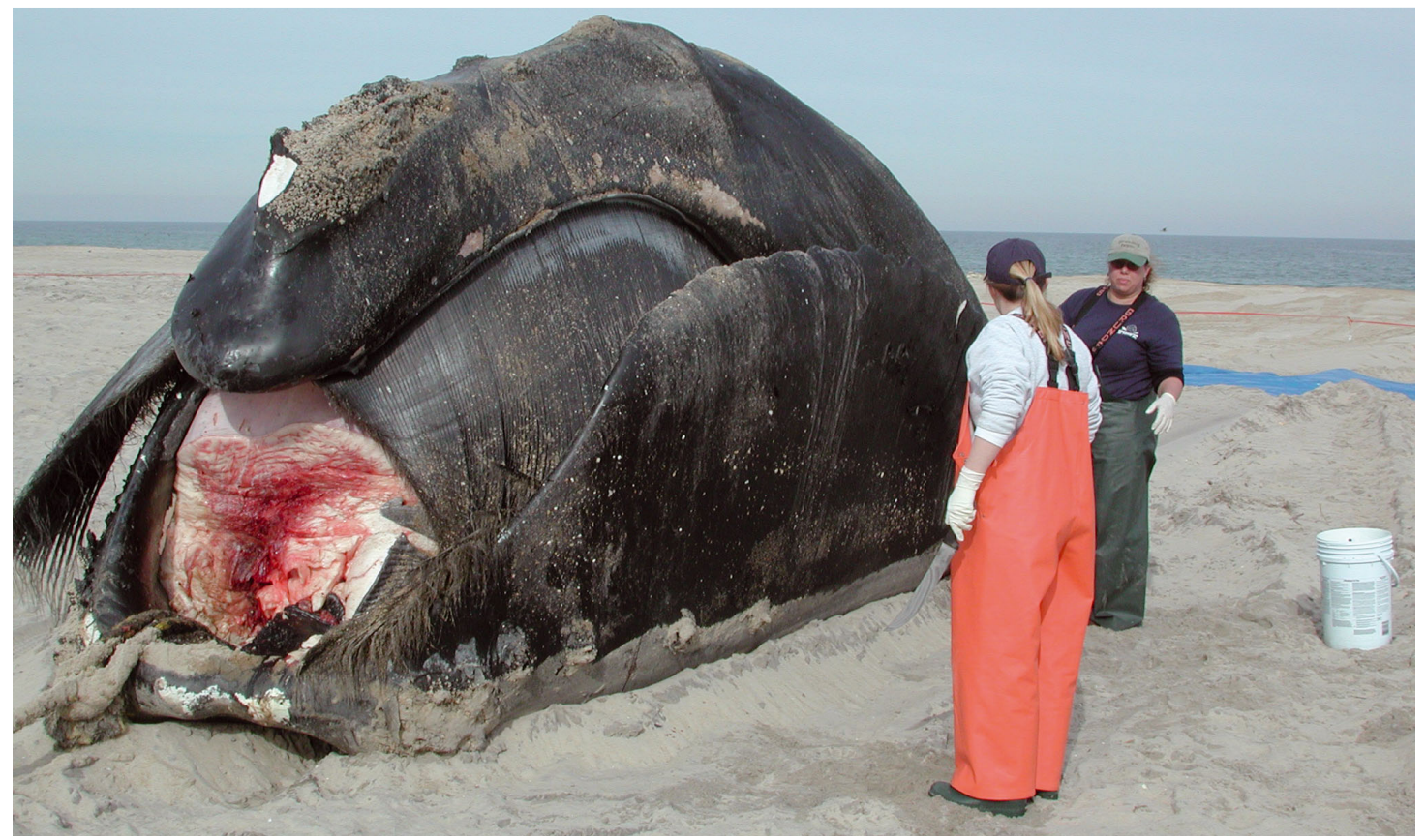

Fig. 5. Front left side of the head of a dead adult right whale showing how the anterior portion of the upper and lower jaws are tapered. The rope was looped around the lower jaw to drag the animal's head up the beach after it was removed from its body at the water's edge. The anterior portion of the tongue has been removed to enable the attachment of the rope which is approximately $5 \mathrm{~cm}$ in diameter and serves as a size reference. Photo: Virginia Aquarium \& Marine Science Center 
for gear (Fig. 5). Although no measurements of the mouth are available, the $5 \mathrm{~cm}$ diameter rope through the lower jaw of the whale in Fig. 5 suggests the anterior section of both jaws taper down to just $10 \mathrm{~cm}$ or so in depth. Therefore, lines floating $10 \mathrm{~s}$ of $\mathrm{cm}$ off the seafloor create a potential entanglement risk for right whales feeding near the seafloor. The lower jaw would hook the line if the whale was feeding right-side up and its upper jaw would hook the line if it was feeding upside down or on its sides (which may explain the presence of mud on just one side of the head). This assessment of potential risk differs from Brillant \& Trippel's (2010) assertion that line floating less than $3 \mathrm{~m}$ above the seafloor in the Bay of Fundy presents a relatively low risk for entanglement. The entanglement risk likely remains high in some nonfeeding situations as well. For example, whales that get mud on their bodies during SAGs are at risk of becoming entangled near the ocean floor if they continue to engage in the usual active twisting, rolling, and thrashing typical of these groups at the surface.

Although NMFS and the states of Massachusetts and Maine have made progress in addressing some of the fishery entanglement issues (Johnson et al. 2005), the continued entanglement-related mortality of right whales shows that more work is needed. Entanglement scarring data shows a steady increase in right whale entanglements over a $20 \mathrm{yr}$ period from $57 \%$ through 1990 (Kraus 1990), to $71.9 \%$ through 2000 (Knowlton et al. 2003), to $75.6 \%$ through 2002 (Knowlton et al. 2005), to $82.9 \%$ through 2009 (Knowlton et al. 2012), and finally to $84.7 \%$ through 2016 (Knowlton et al. 2018). In addition, the observed number of right whales carrying gear (i.e. not just scarred from past, unobserved entanglements) has increased over time as well (Knowlton et al. 2012).

\subsection{Aspects of mud detection data}

While there are limitations to mud detection data (see below), there are several benefits to using this approach for assessing right whale encounters with the seafloor. The analysis can be performed using data that are routinely collected for photo-identification (photographs of the head and body). This increases both the temporal and geographic scope of the investigation. Tag data, on the other hand, are expensive and logistically challenging to obtain, resulting in relatively small sample size and limited temporal and geographic scope. Ideally, a combination of methods should be utilized. The tag data can be paired with the oceanographic data to give a more comprehensive assessment of how right whales use the water column, and the mud-detection data can increase the sample size of whales actually interacting with the seafloor.

There are a number of factors that should be considered when utilizing mud detection data. The numbers presented here are likely a conservative assessment of seafloor encounters. Not all encounters with the seafloor will leave mud (either due to the force of the impact and/or the sediment type), not all mud on an animal will be detected (either because there were no researchers present to document it or the mud was on an unphotographed side of the whale), and the time window for detection is limited as most mud only persists for a matter of hours. There is some over-counting of seafloor encounters (i.e. of the 2008 sightings of identified whales with mud, between 60 [all confirmed mud retention cases] and 277 could have been double counts), but this over-counting is likely more than offset by seafloor encounters that were undetected due to the reasons stated above.

Another factor to consider is that mud persistence on a whale is not consistent across habitats. In some habitats, like the Bay of Fundy, it can persist for hours or days and thus is likely to be detected if the whale is photographed. In other areas, such as the southeast USA, mud persistence can be on the order of minutes. This limited persistence could indicate that the sediment type in the southeast is not as adhesive as the mud in the Bay of Fundy, or that whales in the southeast are not as forceful with their interaction with the seafloor, or both. This variation in persistence may introduce a detection bias. Similarly, the type of survey platform used to collect the photographs impacts the data. Faint patches of mud can be detected from shipboard photographs but not most aerial images. Of all the habitats, the Bay of Fundy has the largest vessel-based photographic effort with as many as 8 boats collecting images there in the early 2000s. The intensive effort in the Bay in some years also allowed for multiple sightings of the same individual on the same day, and thus data from the Bay are over-represented in the analysis of mud retention and acquisition. Finally, seafloor encounters in habitats with little or no mud sediment will be under-represented (e.g. the mid-Atlantic; Fig. 2).

\subsection{Geographic location}

More than $93 \%$ of the seafloor encounters happened in the Bay of Fundy (Table 1), suggesting that right whales would be at high risk of entanglements 
in floating ground lines if gear is present when the whales are in the area. Lobster season in right whale habitat in the Bay generally ends in June and historically has not overlapped with peak right whale occurrence, although some right whales have been seen there in June (Brown et al. 1995, P. Hamilton unpubl. data). Whether there has been increased overlap since the distribution shift described above is not known. There is some evidence that the plankton resource in the Bay is shifting to earlier in the season (Davies et al. 2019), but June surveys in 2018 discovered only one right whale. Because there is so much variation in sightings from year to year, further surveys early in the season are needed.

While the incidence of seafloor encounters is highest in the Bay of Fundy, Jeffreys Ledge is also an area of concern. This area had the second highest seafloor encounter rate (Table 1) which mirrors the findings of Baumgartner et al. (2017). The 2 right whales the latter authors tagged near Jeffreys Ledge during December 2006 dove repeatedly to near the seafloor to forage on concentrated layers of C. finmarchicus. These 2 whales spent the most time of any of the tagged whales within $15 \mathrm{~m}$ of the seafloor $(62 \pm$ $8.4 \%)$. The sample size for both studies is admittedly low; further surveys on Jeffreys Ledge would improve our understanding of right whale seafloor encounters in this area.

\subsection{Conclusion}

It is clear that right whales of all demographic classes (Table 2) interact with the seafloor throughout much of their range (Table 1) and in all months (Fig. 3). Given the increasingly dynamic nature of right whale distributions (Pace et al. 2017, Hayes et al. 2018) which reduces our ability to predict when and where right whales will be, every effort should be made to limit the amount of rope in the water column throughout the species' range-either by reducing fishing effort or implementing ropeless fishing technology (Werner \& McLellan-Press 2017). Given, also, that right whales are regularly making contact with the seafloor, even sinking ground lines resting on the seafloor pose some risk - especially if right whales are intentionally interacting with the sediment there. Sinking groundlines still provide protection for those animals feeding just above the seafloor (Baumgartner et al. 2017) and therefore, until or unless groundlines can be eliminated altogether, should be considered throughout the entire range of this species.
Acknowledgements. This research was supported by the National Marine Fisheries Service, Northeast Fisheries Science Center. This work represents the culmination of years of analysis efforts by Jackie Ciano, Martie Crone, Jane Harrison, Lisa Conger, Beth Pike, and the New England Aquarium right whale team. The North Atlantic Right Whale Consortium and Right Whale Catalog provided the sightings data. New England Aquarium data were collected in US waters under multiple permits issued to Dr. Kraus by the NOAA/NMFS Office of Protected Resources Permit Office and in Canadian waters under permits from the Canadian Department of Fisheries and Oceans. Special thanks to Sue Barco and the Virginia Aquarium \& Marine Science Center for providing the photograph for Fig. 5, and to Brooke Hodge for generating Fig. 2. Finally, we would like to thank 4 anonymous reviewers for their thoughtful comments on the manuscript.

\section{LITERATURE CITED}

Baumgartner MF, Mate BR (2003) Summertime foraging ecology of North Atlantic right whales. Mar Ecol Prog Ser 264:123-135

Baumgartner MF, Wenzel FW, Lysiak NSJ, Patrician MR (2017) North Atlantic right whale foraging ecology and its role in human-caused mortality. Mar Ecol Prog Ser 581:165-181

* Brillant SW, Trippel EA (2010) Elevations of lobster fishery groundlines in relation to their potential to entangle endangered North Atlantic right whales in the Bay of Fundy, Canada. ICES J Mar Sci 67:355-364

* Brown MW, Kraus SD, Gaskin DE, White BN (1994) Sexual composition and analysis of reproductive females in the North Atlantic right whale, Eubalaena glacialis, population. Mar Mamm Sci 10:253-265

Brown MW, Allen JM, Kraus SD (1995) The designation of seasonal right whale conservation zones in the waters of Atlantic Canada. Marine protected areas and sustainable fisheries. Science and Management of Protected Areas Association, Wolfville, p 90-98

Brown MW, Kraus SD, Slay CK, Garrison L (2007) Surveying for discovery, science and management. In: Kraus SD, Rolland RM (eds) The urban whale: North Atlantic right whale at the crossroads. Harvard University Press, Cambridge, MA, p 105-137

* Clarke JT, Kennedy AS, Ferguson MC (2016) Bowhead and gray whale distributions, sighting rates, and habitat associations in the eastern Chukchi Sea, summer and fall 2009-15, with a retrospective comparison to 1982-91. Arctic 69:359-377

* Davies KTA, Brown MW, Hamilton PK, Knowlton AR, Taggart CT, Vanderlaan ASM (2019) Variation in North Atlantic right whale Eubalaena glacialis occurrence in the Bay of Fundy, Canada, over three decades. Endang Species Res 39:159-171

Fortune SME, Koski WR, Higdon JW, Trites AW, Baumgartner MF, Ferguson SH (2017) Evidence of molting and the function of "rock-nosing" behavior in bowhead whales in the eastern Canadian Arctic. PLOS ONE 12:e0186156

Glass AH, Cole TVN, Garron M, Merrick RL, Pace RM III (2010) Mortality and serious injury determinations for baleen whale stocks along the United States eastern seaboard and adjacent Canadian Maritimes, 2004-2008. NOAA Tech Memo NMFS-NE-214 
Goodyear JD (1996) Significance of feeding habitats of North Atlantic right whales based on studies of diel behaviour, diving, food ingestion rates, and prey. $\mathrm{PhD}$ dissertation, University of Guelph

Hamilton PK, Knowlton AR, Marx MK, Kraus SD (1998) Age structure and longevity in North Atlantic right whales (Eubalaena glacialis) and their relation to reproduction. Mar Ecol Prog Ser 171:285-292

Hamilton PK, Knowlton AR, Marx MK (2007) Right whales tell their own stories: the photo-identification catalog. In: Kraus SD, Rolland RM (eds) The urban whale: North Atlantic right whales at the crossroads. Harvard University Press, Cambridge, MA

Hayes SA, Josephson E, Maze-Foley K, Rosel PE (2017) US Atlantic and Gulf of Mexico marine mammal stock assessments - 2016. NOAA Tech Memo NMFS-NE-241

Hayes SA, Gardner S, Garrison L, Henry A, Leandro L (2018) North Atlantic right whales - evaluating their recovery challenges in 2018. NOAA Tech Memo NMFS-NE-247

Johnson AJ, Salvador GS, Kenney JF, Robbins J, Kraus SD, Landry SC, Clapham PJ (2005) Fishing gear involved in entanglements of right and humpback whales. Mar Mamm Sci 21:635-645

Johnson AJ, Kraus SD, Kenney JF, Mayo CA (2007) The entangled lives of right whales and fishermen: Can they coexist? In: Kraus SD, Rolland RM (eds) The urban whale: North Atlantic right whales at the crossroads. Harvard University Press, Cambridge, MA

Knowlton AR, Kraus SD (2001) Mortality and serious injury of northern right whales (Eubalaena glacialis) in the western North Atlantic ocean. J Cetacean Res Manag Spec Issue 2:193-208

Knowlton AR, Kraus SD, Kenney RD (1994) Reproduction in North Atlantic right whales (Eubalaena glacialis). Can J Zool 72:1297-1305

Knowlton AR, Marx MK, Pettis HM, Hamilton PK, Kraus SD (2003) Analysis of scarring on North Atlantic right whales (Eubalaena glacialis): monitoring rates of entanglement interaction. Report to the National Marine Fisheries, Woods Hole, MA

Knowlton AR, Marx MK, Pettis HM, Hamilton PK, Kraus SD (2005) Analysis of scarring on North Atlantic right whales (Eubalaena glacialis): monitoring rates of entanglement interaction: 1980-2002. Final report to the National Marine Fisheries Service, Woods Hole, MA

Knowlton AR, Hamilton PK, Marx MK, Pettis HM, Kraus SD (2012) Monitoring North Atlantic right whale Eubalaena glacialis entanglement rates: a $30 \mathrm{yr}$ retrospective. Mar Ecol Prog Ser 466:293-302

Knowlton AR, Robbins J, Landry S, McKenna HA, Kraus SD, Werner TB (2016) Effects of fishing rope strength on the severity of large whale entanglements. Conserv Biol 30: 318-328

Knowlton AR, Marx MK, Hamilton PK, Pettis HM, Kraus SD (2018) Task 2: final report on 2016 right whale entanglement scar coding efforts. In: Hamilton PK, Knowlton AR, Hagbloom MN, Howe KR and others (eds) Maintenance of the North Atlantic right whale catalog, whale scarring and visual health databases, anthropogenic injury case studies, and near real-time matching for biopsy efforts, entangled, injured, sick, or dead right whales. Final report to the National Marine Fisheries Service, Woods Hole, MA

Kraus SD (1990) Rates and potential causes of mortality in North Atlantic right whales (Eubalaena glacialis). Mar Mamm Sci 6:278-291
Kraus SD, Hatch JJ (2001) Mating strategies in the North Atlantic right whale (Eubalaena glacialis). J Cetacean Res Manag Spec Issue 2:237-244

Kraus SD, Moore KE, Price CE, Crone MJ, Watkins WA, Winn HE, Prescott JH (1986) The use of photographs to identify individual North Atlantic right whales (Eubalaena glacialis). Rep Int Whal Comm Spec Issue 10:145-151

Kraus SD, Brown MW, Caswell H, Clark CW and others (2005) North Atlantic right whales in crisis. Science 309: 561-562

Kraus SD, Kenney RD, Mayo CA, McLellan WA, Moore MJ, Nowacek NP (2016) Recent scientific publications cast doubt on North Atlantic right whale future. Front Mar Sci $3: 137$

Lockyer C (1984) Review of baleen whale (Mysticeti) reproduction and implications for management. Rep Int Whaling Comm 6:27-50

Mate BR, Nieukirk SL, Kraus SD (1997) Satellite-monitored movements of the northern right whale. J Wildl Manag 61:1393-1405

Mayo CA, Marx MK (1990) Surface foraging behavior of the North Atlantic right whale Eubalaena glacialis, and associated zooplankton characteristics. Can J Zool 68: 2214-2220

* McKiernan D, Pol M, Malkowski V (2002) A study of the underwater profiles of lobster trawl ground lines. Massachusetts Division of Marine Fisheries. https://www.mass. gov/files/2017-08/groundline-report.pdf

Moore MJ, van der Hoop JM (2012) The painful side of trap and fixed net fisheries: chronic entanglement of large whales. J Mar Biol 2012:230653

*Moore SE, Grebmeier JM, Davies JR (2003) Gray whale distribution relative to forage habitat in the northern Bering Sea: current conditions and retrospective summary. Can J Zool 81:734-742

NMFS (2005) Recovery plan for the North Atlantic right whale (Eubalaena glacialis). National Marine Fisheries Service, Silver Spring, MD

NMFS (2007) Taking of marine mammals incidental to commercial fishing operations; Atlantic large whale take reduction plan regulations. Fed Regist 72: 57103-57194

Pace RM III, Cole TVN, Henry AG (2014) Incremental fishing gear modifications fail to significantly reduce large whale serious injury rates. Endang Species Res 26:115-126

* Pace RM III, Corkeron PJ, Kraus SD (2017) State-space mark-recapture estimates reveal a recent decline in abundance of North Atlantic right whales. Ecol Evol 7: 8730-8741

*Parks SE, Brown MW, Conger LA, Hamilton PK and others (2007) Occurrence, composition and potential functions of North Atlantic right whale (Eubalaena glacialis) surface active groups. Mar Mamm Sci 23:868-887

Payne R, Brazier O, Dorsey EM, Perkins JS, Rowntree VJ, Titus A (1983) External features in southern right whales (Eubalaena australis) and their use in identifying individuals. In: Payne R (ed) Communication and behavior of whales. Westview Press, Boulder, CO, p 371-445

* Robbins J, Knowlton AR, Landry S (2015) Apparent survival of North Atlantic right whales after entanglement in fishing gear. Biol Conserv 191:421-427

Sharp SM, McLellan WA, Rotstein DS, Costidis AM and others (2019) Gross and histopathologic diagnoses from North Atlantic right whale Eubalaena glacialis mortalities between 2003 and 2018. Dis Aquat Org 135:1-31 
USGS (2005) CONMAPSG: continental margin mapping (CONMAP) sediments grainsize distribution for the United States east coast continental margin: open-file report 2005-1001. US Geological Survey, Coastal and Marine Geology Program, Woods Hole Science Center, Woods Hole, MA

van der Hoop JM, Moore MJ, Barco SG, Cole TVN and others (2013) Assessment of management to mitigate anthropogenic effects on large whales. Conserv Biol 27:121-133

van der Hoop JM, Corkeron P, Kenney J, Landry S, Morin D, Smith J, Moore MJ (2016) Drag from fishing gear entangling North Atlantic right whales. Mar Mamm

Editorial responsibility: B. Louise Chilvers,

Palmerston North, New Zealand
Sci 32:619-642

* Visser A, Jónasdóttir S (1999) Lipids, buoyancy and the seasonal vertical migration of Calanus finmarchicus. Fish Oceanogr 8:100-106

Werner T, McLellan-Press K (2017) Global assessment of large whale entanglement and bycatch reduction in fixed fishing gear. Consortium for Wildlife Bycatch Reduction, New England Aquarium, Boston, MA

Wursig B, Dorsey EM, Richardson WJ, Wells RS (1989) Feeding, aerial and play behavior of the bowhead whale, Balaena mysticetus, summering in the Beaufort Sea. Aquat Mamm 15:27-37

Submitted: January 3, 2019; Accepted: April 28, 2019 Proofs received from author(s): July 9, 2019 